\title{
Bone loss and the aromatase inhibitors
}

\author{
J Lester' and R Coleman*,I \\ 'Academic Unit of Clinical Oncology, Cancer Research Centre, Weston Park Hospital, Sheffield SIO 2SJ, UK
}

The increasing use of systemic adjuvant therapies has considerably improved the prognosis from early breast cancer. However, some of these therapies affect bone metabolism, resulting in osteoporosis. Aromatase inhibitors lower circulating oestrogen levels to almost unrecordable levels in postmenopausal women, predisposing them to bone loss with an increase in fracture risk. Ongoing clinical trials are favouring the use of the aromatase inhibitors over tamoxifen and this may advocate greater use of these drugs in the future. Strategies for the identification and management of treatment-induced bone loss are currently being defined. British Journal of Cancer (2005) 93(Suppl I), S16-S22. doi:I0.1038/sj.bjc.660269I www.bjcancer.com (C) 2005 Cancer Research UK

Keywords: aromatase inhibitors; bone loss; tamoxifen; steroidal; nonsteroidal

The incidence of breast cancer is rising steadily and at present is the most common cancer in women. New therapeutic options are improving survival and this is exposing an increasing population to the late complications of breast cancer and its treatment. In the last few years, research has shown that breast cancer has important implications for bone health. Of major concern is the development of bone metastasis, but many breast cancer patients are at increased risk for developing osteoporosis, which is also associated with marked morbidity and mortality (Adachi et al, 2002; Cummings and Melton, 2002; Hasserius et al, 2003; Marks et al, 2003).

The pathogenesis of osteoporosis is complicated with many factors involved, although oestrogen deficiency is perhaps the most important factor. The increasing use of chemotherapy in young women leading to premature menopause, and the introduction of aromatase inhibitors into the adjuvant setting for postmenopausal women have improved outcome, but have clinically important consequences on bone mineral density (BMD) and fracture risk.

Bone mineral density is a surrogate marker of lifetime exposure to oestrogen and therefore is a risk factor for developing breast cancer (Cauley et al, 1996; Zhang et al, 1997). Consequently, newly diagnosed breast cancer patients have a higher average BMD than the normal age-matched population (van der Klift et al, 2003). Despite this, it is becoming increasingly evident that breast cancer and its treatment are associated with the development of osteoporotic fracture. In a study by Kanis et al (1999), 1210 patients with breast cancer but no evidence of bone metastasis were investigated. The incidence of vertebral fracture was $5.4 \%$ in the newly diagnosed breast cancer patients compared with only $1.5 \%$ in age-matched women without breast cancer.

The reductions in circulating oestrogen levels that occur at the menopause are associated with a rapid deterioration in bone mass by as much as $3 \%$ per year for the first 5 years after the menopause (Riggs et al, 1998). After the menopause, intrinsic production of oestrogen from androgens largely occurs in nonovarian tissues

*Correspondence: Professor R Coleman;

E-mail: R.E.Coleman@sheffield.ac.uk such as fat, muscle, skin and liver as a result of the activity of the aromatase enzyme complex (Sluijmer et al, 1995). The resulting low levels of circulating oestrogen help to prevent a more exaggerated bone loss (Cummings et al, 1998a).

\section{CAUSES OF ACCELERATED BONE LOSS IN BREAST CANCER}

There are many treatments for breast cancer that increase the risk of osteoporosis; these are outlined below (Table 1).

\section{Chemotherapy}

Indirect effects The use of chemotherapy in premenopausal patients commonly induces a sudden deterioration in oestrogen production and often an early menopause. A study by Shapiro et al (2001) investigated 49 premenopausal stage 1 and 2 breast cancer patients treated with adjuvant chemotherapy. After 1 year, 35 (71\%) patients were found to have ovarian failure and these patients lost on average $4.0 \%(P=0.0001)$ of the lumber spine BMD after just 6 months. This rate of bone loss was maintained at 12 months with a further $3.7 \%(P=0.0001)$ of bone loss.

Direct effects Studies on rat skeletons after the administration of methotrexate suggest that chemotherapy may have a direct impact on bone by inhibiting proliferation. After treatment, bone histomorphometry showed a significant reduction in bone volume, strength and mineralisation surface compared with controls $(P<0.05)$ (Wheeler et al, 1995).

A study by Greep et al (2003) assessed postmenopausal patients who are not susceptible to the ovarian suppression caused by chemotherapy. The changes observed in BMD suggested a possible direct effect of chemotherapy. Although no significant change in BMD T-score (based on peak bone mass) was seen, the Z-score (age-adjusted difference from the mean) did fall more rapidly than in control patients. The average change in Z-score for chemotherapy patients was $-0.65(P=0.0002)$ at the total hip and -0.60 $(P=0.05)$ at the lumbar spine. 
Table I Agents causing bone loss in breast cancer patients

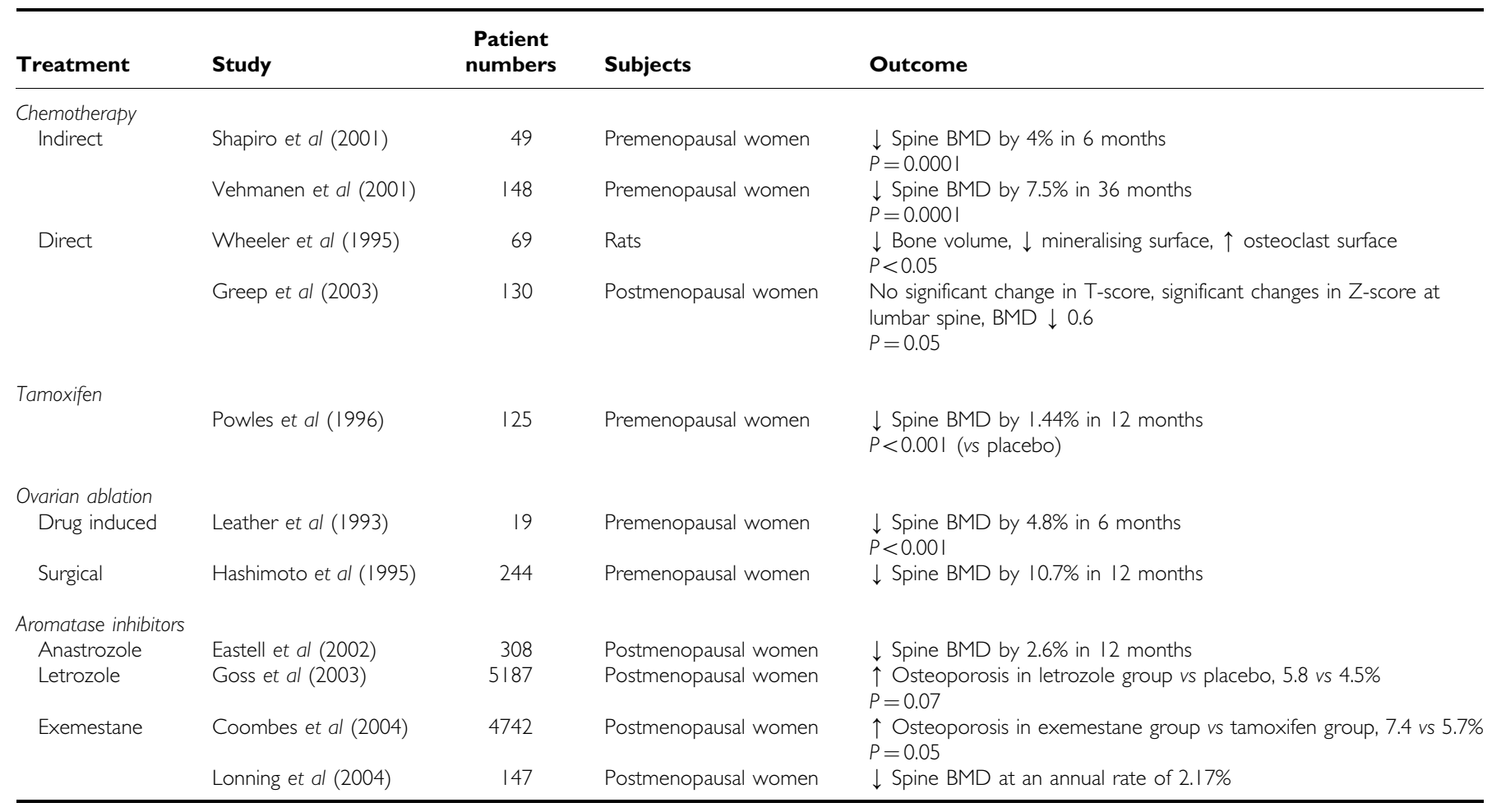

$\mathrm{BMD}=$ bone mineral density.

These studies suggest that chemotherapy may have direct effects on bone metabolism, particularly bone formation, but overall, premature ovarian failure is the major cause of chemotherapyinduced bone loss.

\section{Tamoxifen}

Tamoxifen has a complicated mechanism of action with potent antioestrogenic effects on the breast, but also partial oestrogen agonist effects on bone, uterus and lipids. The partial agonist effect appears to have varying impacts on bone metabolism depending on the intrinsic circulating levels of oestrogen. Postmenopausal women receiving tamoxifen therefore may be protected from the development of osteoporosis, due to the mild oestrogen agonist action. Love et al (1992) conducted a placebo-controlled trial investigating 140 postmenopausal women with breast cancer receiving tamoxifen. After 2 years, BMD of the lumbar spine increased by $0.61 \%$ per year in the tamoxifen group $(P=0.04)$ and declined by $1.0 \%$ per year in the placebo group $(P<0.001)$. A similar study by Kristensen et al (1994) also showed that postmenopausal women on tamoxifen therapy had a significantly higher BMD than placebo-treated patients $(P<0.0074)$.

Premenopausal women, however, are rendered relatively oestrogen deficient by tamoxifen and as a result may be more prone to osteoporosis in later life. A study by Powles et al (1996) investigated 125 premenopausal women and found that they lost on average $1.44 \%$ of their lumbar spine BMD every year on tamoxifen treatment. Placebo-treated patients, however, showed a modest gain in their BMD $(P<0.001)$ (Figure 1$)$.

\section{Ovarian ablation/suppression}

Surgical Surgical removal of the ovaries is an effective therapy for premenopausal patients with breast cancer (Ingle et al, 1986;
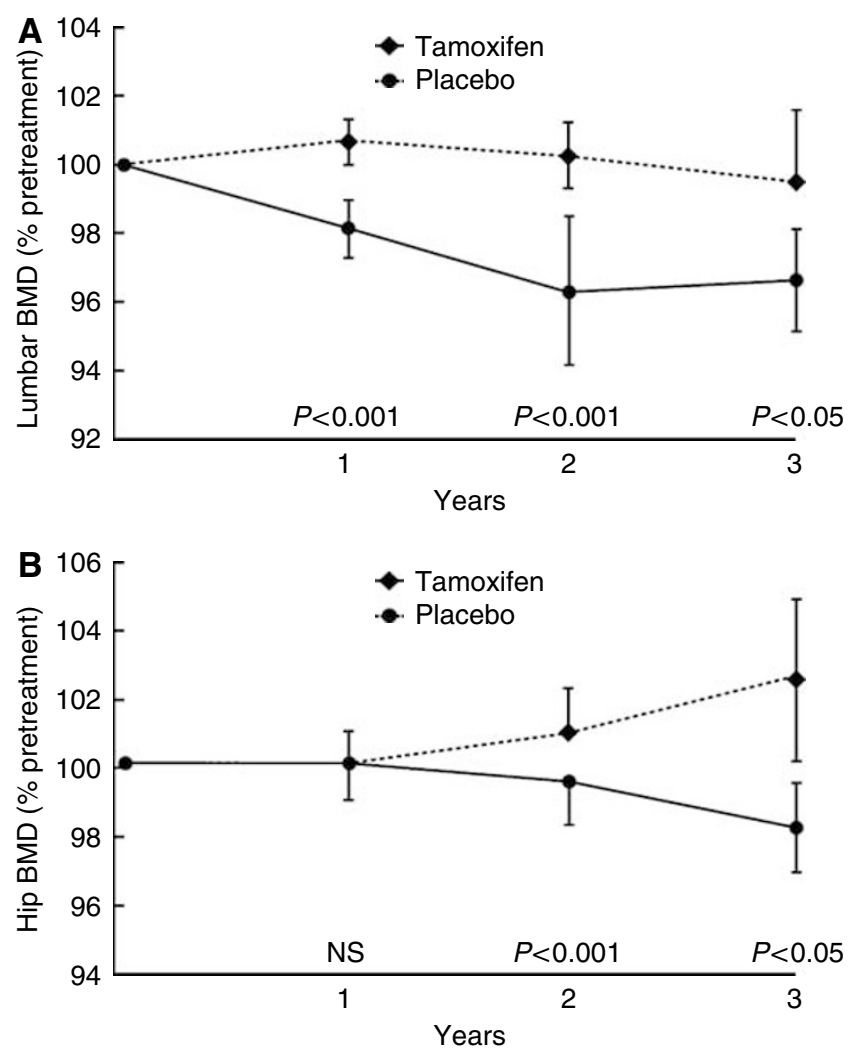

Figure I Changes in BMD of $(\mathbf{A})$ the hip and (B) the spine in premenopausal women on tamoxifen or placebo. Reproduced with permission from Powles et al (1996). 
Conte et al, 1989; Taylor et al, 1998). It is also clear that the procedure is associated with a rapid decline in oestrogen and bone strength. Hashimoto et al (1995) investigated 244 women who were having regular menstrual cycles up until the point of surgical oophorectomy. After 1 year, the mean BMD declined by $10.7 \%$.

Drug induced The gonadorelin analogue, goserelin, is licensed for the treatment of premenopausal patients with advanced breast cancer and is increasingly used in the adjuvant setting. Goserelin induces ovarian failure followed by a rapid decline in circulating oestrogen. As a consequence, BMD can deteriorate by as much as $4.8 \%$ within the lumbar spine after just 6 months (Leather et al, 1993).

\section{Aromatase inhibitors}

Aromatase inhibitors are potent inhibitors of oestrogen production and at present are commonly used in patients with metastatic disease and in some early breast cancer patients who are unsuitable for treatment with tamoxifen. Two types of aromatase inhibitor are currently available, which have different mechanisms of action. The nonsteroidal agents (anastrozole, letrozole and aminoglutethimide) are reversible inhibitors, while steroidal agents (exemestane and formestane) are irreversible inactivators of the aromatase enzyme. The third-generation aromatase inhibitors anastrozole, letrozole and exemestane are the most powerful drugs available resulting in approximately $96-99 \%$ enzyme inhibition (Dowsett et al, 1995; Geisler et al, 1996, 1998). This marked reduction in oestradiol would be expected to have profound effects on bone physiology. The decision on which drugs to use in the future will depend upon the clarity of the results of trials in metastatic disease and adjuvant therapy, as well as 'head to head' comparison of the agents (Cummings, 2002).

Anastrozole Anastrozole has shown clear advantages over megestrol acetate as second-line therapy for advanced breast cancer and to be at least as good as tamoxifen for first-line therapy (Buzdar et al, 1998; Nabholtz et al, 2000). It is also being used increasingly in the adjuvant setting. Preliminary results from the Arimidex, Tamoxifen Alone or in Combination (ATAC) trial have been published (ATAC, 2002). The study included over 9000 postmenopausal patients who had completed primary therapy for breast cancer and who were eligible for endocrine therapy. Patients were randomised equally between anastrozole, tamoxifen or a combination of both. Results published after a median follow-up of 33.3 months found that anastrozole improved disease-free survival, time to disease recurrence and incidence of contralateral primary breast cancer compared with both tamoxifen and the combination of drugs. Updated results confirmed these early observations (Baum et al, 2003).

From the perspective of adverse events, anastrozole was better tolerated except for the occurrence of musculoskeletal side effects and the incidence of fractures, mainly of the spine and wrist. After a median follow-up of 37 months, the incidence of all fractures was $7.1 \%$ in the anastrozole group and $4.4 \%$ in the tamoxifen group $(P<0.0001)$ (ATAC, 2002) (Table 2). Although the fracture rate in anastrozole-treated women appeared to plateau after around 18 months, with no progressive increase in fracture risk (Table 3), the increased fracture risk seen in the anastrozole patients still remained significant $(P<0.0001)$ (Howell, 2003; Locker and Eastell, 2003). The fracture rate per 1000 women years was 21.55 with anastrozole compared with 13.44 with tamoxifen. A population of healthy women of similar median age would be expected to have a fracture rate per 1000 women years of 19.10 (Writing Group for the Women's Health Initiative Investigators, 2002).

The bone subprotocol of the ATAC trial investigated 308 patients and assessed them for any changes in BMD and bone turnover markers (Eastell et al, 2002). After 2 years treatment with
Table 2 Incidence of fracture in ATAC trial (adapted with permission from ATAC Trialists' Group, 2002)

\begin{tabular}{lcc}
\hline & Anastrozole $(\boldsymbol{n}=\mathbf{3 0 9 2})$ & Tamoxifen $(\mathbf{n}=\mathbf{3 0 9 4})$ \\
\hline Total fractures & $183(5.9 \%)$ & $115(3.7 \%)$ \\
Spine fractures & $23(0.7 \%)$ & $10(0.3 \%)$ \\
Wrist fractures & $36(1.2 \%)$ & $25(0.8 \%)$ \\
Hip fractures & $11(0.4 \%)$ & $13(0.4 \%)$ \\
\hline
\end{tabular}

ATAC trial = Arimidex Tamoxifen Alone or in Combination trial.

Table 3 6-monthly fracture rates per 100 patients at a median follow-up of 37 months in the ATAC trial (Howell, 2003; Locker and Eastell, 2003)

\begin{tabular}{lccc}
\hline & \multicolumn{2}{c}{$\begin{array}{c}\text { 6-monthly fracture rates/100 } \\
\text { patients }\end{array}$} & \\
\cline { 2 - 3 } $\begin{array}{l}\text { Time } \\
\text { (months) }\end{array}$ & $\begin{array}{c}\text { Anastrozole } \\
(\mathbf{n}=\mathbf{3 0 9 2})\end{array}$ & $\begin{array}{c}\text { Tamoxifen } \\
(\mathbf{n = 3 0 9 3 )}\end{array}$ & $\begin{array}{c}\text { Anastrozole/ } \\
\text { tamoxifen 6-month } \\
\text { hazard ratio }\end{array}$ \\
\hline 6 & 1.11 & 0.99 & 1.14 \\
12 & 0.93 & 0.58 & 1.61 \\
18 & 1.36 & 0.69 & 1.98 \\
24 & 1.57 & 0.61 & 2.57 \\
30 & 1.39 & 0.96 & 1.45 \\
36 & 1.09 & 0.66 & 1.66 \\
42 & 1.50 & 1.37 & 1.09 \\
48 & 1.07 & 0.80 & 1.34 \\
\hline
\end{tabular}

ATAC trial = Arimidex, Tamoxifen Alone or in Combination trial.

anastrozole, the BMD had fallen on average by $4.0 \%$ in the lumbar spine and $3.2 \%$ in the hip. There was also a $15 \%$ increase in the bone resorption marker N-terminal telopeptide (NTX) and a $21 \%$ increase in bone alkaline phosphatase, a bone formation marker. At this early stage, this is clear evidence that anastrozole reduces BMD in postmenopausal women and does not have the bone protective effects of tamoxifen.

Letrozole Letrozole is superior to megestrol acetate in the treatment of advanced breast cancer and is clearly superior to tamoxifen as first-line therapy in high-risk or advanced disease (Buzdar et al, 2001; Ellis et al, 2001; Mouridsen et al, 2001). Recently, Goss et al (2003) investigated the role of letrozole after treatment with 5 years of adjuvant tamoxifen. Patients with breast cancer $(n=5187)$ were randomised to further treatment with letrozole or placebo after the completion of 5 years of tamoxifen therapy. After a median follow-up of just 2.4 years, the estimated 4 -year disease-free survival was $93 \%$ in the letrozole group and $87 \%$ in the placebo group $(P<0.001)$. Only $61(2.4 \%)$ patients treated with letrozole developed recurrent disease compared to $106(4.1 \%)$ in the placebo group. Unfortunately, as the study was discontinued early, the long-term effects of letrozole are not yet known. However, at this early stage, more diagnoses of osteoporosis have been made in the letrozole group compared with the placebo group, at 5.8 and $4.5 \%$ respectively $(P=0.07)$, suggesting that, like anastrozole, letrozole increases bone loss and fracture risk (Goss et al, 2003). The first results of a specific bone subprotocol evaluating changes in BMD and bone markers were presented by Perez et al (2004). Letrozole patients $(n=122)$ experienced a significant decrease in total hip BMD compared with placebo $(n=104)$ from baseline $(-3.6 v s-0.71 \%, P=0.044)$ and a significant decrease in lumbar spine BMD ( -0.35 vs $-0.7 \%$, $P=0.008)$ at 24 months. Letrozole also increased the bone resorption marker NTX. In addition, more women receiving letrozole became osteoporotic at the $\mathrm{L} 2-4$ spine by BMD criteria 
than placebo-treated women, although the difference was not significant (3.3 vs $0 \%)$.

Small short-term studies have shown that letrozole has an impact on markers of bone turnover. Harper-Wynne et al (2001) found that C-terminal telopeptide (CTX), a marker of bone resorption, increased from a mean of 2300 to 2828 after 3 months of letrozole therapy $(P<0.005)$. Over a 12 -week period, Goss et al (2002) found that letrozole therapy reduced the bone formation marker, bone-specific alkaline phosphatase (BAP), by $20.1 \%$ while the bone resorption marker CTX increased by $11.4 \%$. The study also investigated the impact of exemestane on bone turnover as discussed below.

The ZOFAST study is presently recruiting postmenopausal breast cancer patients with normal bone density. Patients are treated with letrozole and randomised to either immediate intravenous zoledronate or to a delayed phase of treatment based on changes in BMD. Subsequent DXA scans will determine if zoledronate can prevent bone loss in these patients and when they should be considered for treatment with a bisphosphonate. Initial results from the study were reported at the end of 2004, with 587 patients having baseline BMD data (Brufsky et al, 2004). At that point, there was a $3.33 \%$ difference in lumbar spine BMD in favour of upfront treatment with zoledronate and a $2.42 \%$ difference in favour of upfront treatment with total hip BMD.

Exemestane Exemestane is a steroidal aromatase inhibitor, which is also superior to megestrol acetate (Kaufmann et al, 2000). There are recent data indicating superior efficacy to tamoxifen (Paridaens et al, 2004) and the drug retains activity after treatment with nonsteroidal aromatase inhibitors. Exemestane is also being evaluated in the adjuvant setting. Results from direct comparison with tamoxifen are not expected for some time. However, the first data from a trial testing the sequence of tamoxifen for 2-3 years followed by exemestane for $2-3$ years $v s$ standard treatment with 5 years tamoxifen have recently been presented (Coombes et al, 2004). After a median follow-up of 30.6 months, significant reductions in first cancer-related events, disease-free survival and contralateral breast cancer were seen in the exemestane group. There was a nonsignificant increase in osteoporosis for both treatment groups, with $171(7.4 \%)$ exemestane-treated patients and $134(5.7 \%)$ tamoxifen-treated patients diagnosed with osteoporosis $(P=0.05$ exemestane $v s$ tamoxifen). Similarly, there was a nonsignificant increase in reported fractures, with a trend towards increased fracture rate seen in the exemestane group (exemestane $3.1 \%$ vs tamoxifen $2.3 \%$; $P=0.08$ ).

The first data from the bone subprotocol of 206 patients have recently become available (Coleman et al, 2004). Patients who switched from tamoxifen to exemestane lost $2.7 \%$ lumbar spine BMD after 6 months and 3.2\% after 12 months. For patients who continued on tamoxifen, the mean rates of bone loss were 0.2 and $0.2 \%$ at the spine after 6 and 12 months. These differences were significant at both time points $(P<0.0001)$. The rapid decline in BMD after 6 months may be due to the withdrawal of tamoxifen as much as the introduction of exemestane. Further data from measurements after 2 years will help to evaluate subsequent bone loss.

A study to investigate the effect of exemestane and letrozole on markers of bone turnover in postmenopausal women was recently updated at the San Antonio Breast Cancer Symposium (Goss et al, 2002). Exemestane was associated with a reduction in bone resorption markers compared with letrozole. Urinary CTX increased by $11.4 \%$ in patients treated with letrozole, but in the exemestane group it declined by $23.4 \%$. This suggested that exemestane may have a bone-preserving action that is not seen with other aromatase inhibitors. However, the trial only involved 60 patients and follow-up was just 12 weeks. In contrast, a small substudy by Martinetti et al (2003) found that exemestane increased levels of bone turnover markers. A total of 23 postmenopausal patients with or without bone metastasis from metastatic breast cancer were randomised to treatment with exemestane, and samples for BAP, CTX and insulin-like growth factor were taken after 8 weeks. In the population as a whole, exemestane resulted in significant increases in both BAP and CTX $(P<0.01)$.

Very recently, the preliminary results of a study comparing adjuvant exemestane with placebo in low-risk breast cancer patients were presented by Lonning et al (2004). At 24 months, CTX had increased from baseline by $35 \%$ with exemestane and fallen by $5 \%$ on placebo. Bone formation markers also rose, with changes in a variety of bone formation markers that were somewhat greater than might have been expected through normal bone cell coupling. The authors suggested that this reflected the anabolic action of the main metabolite of exemestane, 17-hydro exemestane. In terms of BMD, the same group reported an annual bone loss of 2.17 and $2.72 \%$ at the spine and hip, respectively (Lonning et al, 2004). Surprisingly, bone loss in the placebo group was greater than expected at 1.84 and $1.48 \%$ at the spine and hip, respectively, and so there was no significant difference between the two groups, although a clear trend for more rapid bone loss on exemestane was evident. None of the women were taking calcium or vitamin D supplements, and in Scandinavia at a median age of over 60 years a high proportion would be expected to be vitamin $\mathrm{D}$ deficient. This may have confounded the results somewhat. Overall, despite the weak androgenic effects of exemestane, it is likely that the profound suppression of circulating oestrogens caused by the potent inhibition of aromatase will override this and, as with the nonsteroidal aromatase inhibitors, promote accelerated bone loss.

\section{TREATMENT}

\section{Vitamin supplements}

Calcium and vitamin D supplements are of benefit in preventing osteoporotic fracture in elderly women and may slow the development of osteoporosis in the over 65 years age group (Goss et al, 2003; Martinetti et al, 2003). These supplements have relatively few side effects and should be taken on a routine basis both alone and in combination with antiresorptive therapy.

\section{Antiresorptives}

Bisphosphonates The bisphosphonates are potent inhibitors of osteoclast function and can improve BMD of the lumbar spine by $5-10 \%$ in 2 years. This degree of improvement correlates with a reduction in fracture risk by approximately 50\% (Eastell, 1998). Bisphosphonates of proven clinical benefit in treating osteoporosis by reducing fracture rates include alendronate (Liberman et al, 1995; Black et al, 1996, 2000; Cummings et al, 1998b) and risedronate (Harris et al, 1999; Reginster et al, 2000).

Presently available intravenous bisphosphonates include pamidronate, zoledronic acid and ibandronate. Zoledronic acid can be given annually at a dose of $4 \mathrm{mg}$ and is as potent as daily oral preparations (Reid et al, 2002). In the treatment of cancer-induced bone loss, several studies have shown the benefit of using bisphosphonates to preserve BMD and presumably therefore the prevention of osteoporosis. Delmas et al (1997) reported on the use of risedronate to prevent bone loss associated with chemotherapy-induced early menopause.

Powles et al (1998) recruited more than 300 women with primary operable breast cancer from the adjuvant clodronate trial. After 2 years, patients treated with placebo lost on average $1.88 \%$ of their lumbar spine BMD. Clodronate-treated patients however lost just $0.16 \%(P=0.04)$. Gnant et al $(2002)$ are presently investigating the effect of intravenous zoledronic acid therapy on 
premenopausal breast cancer patients treated with goserelin and tamoxifen or goserelin and anastrozole. Early results from this study show a significant benefit in favour of zoledronic acid for BMD of the lumbar spine and hip $(P<0.0001)$ for the patients treated with zoledronic acid.

\section{SUMMARY}

At the time of diagnosis, breast cancer patients have a somewhat higher mean BMD compared with age-matched controls. Despite this, there is evidence that patients with breast cancer are at a greater risk for developing osteoporosis. Future trends in the treatment of breast cancer are likely to advocate the use of aromatase inhibitors, which will exacerbate this problem. One way to approach this would be to screen all breast cancer patients with regular DXA scans, and treat them with bisphosphonates as appropriate. However, this would put a major strain on resources and is unlikely to be cost effective.

Consideration of risk factors for osteoporosis and fracture may help identify patients who would benefit most from investigations into their bone density. Clear evidence-based guidelines would help physicians identify which patients to investigate and provide effective treatment, and may open the door to easier access to DXA. The American Society of Clinical Oncology (ASCO) (Hillner et al, 2003) recognised this problem and recently published guidelines to help identify patients at high risk by a series of criteria and suggest treatment depending upon results of DXA scans of the hip or spine.

\section{REFERENCES}

Adachi JD, Ioannidis G, Olszynski WP, Brown JP, Hanley DA, Sebaldt RJ, Petrie A, Tenenhouse A, Stephenson GF, Papaioannou A, Guyatt GH, Goldsmith CH (2002) The impact of incident vertebral and non-vertebral fractures on health related quality of life in postmenopausal women. BMC Musculoskelet Disord 3(1): 11

ATAC Trialists' Group (2002) Anastrozole alone or in combination with tamoxifen versus tamoxifen alone for adjuvant treatment of postmenopausal women with early breast cancer: first results of the ATAC randomised trial. Lancet 359: 2131-2139

Baum M, Buzdar A, Cuzick J, Forbes J, Houghton J, Howell A, Sahmoud T, The ATAC (Arimidex, Tamoxifen Alone or in Combination) Trialists' Group (2003) Anastrozole alone or in combination with tamoxifen versus tamoxifen alone for adjuvant treatment of postmenopausal women with early-stage breast cancer: results of the ATAC (Arimidex, Tamoxifen Alone or in Combination) trial efficacy and safety update analyses. Cancer 98(9): $1802-1810$

Black DM, Cummings SR, Karpf DB, Cauley JA, Thompson DE, Nevitt MC, Bauer DC, Genant HK, Haskell WL, Marcus R, Ott SM, Torner JC, Quandt SA, Reiss TF, Ensrud KE (1996) Randomised trial of effect of alendronate on risk of fracture in women with existing vertebral fractures. Lancet 348: 1535-1541

Black DM, Thompson DE, Bauer DC, Ensrud K, Musliner T, Hochberg MC, Nevitt MC, Suryawanshi S, Cummings SR, Fracture Intervention Trial (2000) Fracture risk reduction with alendronate in women with osteoporosis: the fracture intervention trial. J Clin Endocrinol Metab 85(11): $4118-4124$

Brufsky A, Harker G, Beck T, Carroll R, Tan-Chiu E, Seidler C, Lacema L, Thomas E, Perez E, Z-FAST Study Group (2004) Zoledronic acid (ZA) for prevention of cancer treatment-induced bone loss (CTIBL) in postmenopausal women (PMW) with early breast cancer (BCa) receiving adjuvant letrozole (Let): preliminary results of the Z-FAST trial. 27th Annual San Antonio Breast Cancer Symposium, December 8-11, 2004, San Antonio, Texas. Abstract 1114

Buzdar A, Douma J, Davidson N, Elledge R, Morgan M, Smith R, Porter L, Nabholtz J, Xiang X, Brady C (2001) Phase III, multicenter, double-blind, randomized study of letrozole, an aromatase inhibitor, for advanced breast carcinoma versus megestrol acetate. J Clin Oncol 19: 3357-3366

Buzdar AU, Jonat W, Howell A, Jones SE, Blomqvist CP, Vogel CL, Eiermann W, Wolter JM, Steinberg M, Webster A, Lee D (1998) Anastrozole versus megestrol acetate in the treatment of postmenopausal women with advanced breast carcinoma: results of a survival update based on a combined analysis of data from two mature phase III trials. Arimidex Study Group. Cancer 83: $1142-1152$

Cauley JA, Lucas FL, Kuller LH, Vogt MT, Browner WS, Cummings SR (1996) Bone mineral density and risk of breast cancer in older women: the study of osteoporotic fractures. JAMA 276(17): 1404-1408

Coleman RE, Banks LM, Hall E, Price D, Girgis S, Bliss JM, Coombes RC (2004) Intergroup exemestane study: 1 year results of the bonesubprotocol. Breast Cancer Res Treat 88(Suppl. 1): S35 (Abstract 402)

Conte CC, Nemoto T, Rosner D, Dao TL (1989) Therapeutic oophorectomy in metastatic breast cancer. Cancer 64(1): 150 - 153

Coombes RC, Hall E, Gibson LJ, Paridaens R, Jassem J, Delozier T, Jones SE, Alvarez I, Bertelli G, Ortmann O, Coates AS, Bajetta E, Dodwell D, Coleman RE, Fallowfield LJ, Mickiewicz E, Andersen J, Lonning PE,
Cocconi G, Stewart A, Stuart N, Snowdon CF, Carpentieri M, Massimini G, Bliss JM, Intergroup Exemestane Study (2004) A randomized trial of exemestane after two to three years of tamoxifen therapy in postmenopausal women with primary breast cancer. $N$ Engl J Med 350(11): $1081-1092$

Cummings F (2002) Evolving uses of hormonal agents for breast cancer therapy. Clin Ther 24(Suppl C): S3-S25

Cummings F, Melton J (2002) Epidemiology and outcomes of osteoporotic fractures. Lancet 359: $1761-1767$

Cummings SR, Browner WS, Bauer D, Stone K, Ensrud K, Jamal S, Ettinger B (1998a) Endogenous hormones and the risk of hip and vertebral fractures among older women. N Engl J Med 339(11): 733-738

Cummings SR, Black DM, Thompson DE, Applegate WB, Barrett-Connor E, Musliner TA, Palermo L, Prineas R, Rubin SM, Scott JC, Vogt T, Wallace $\mathrm{R}$, Yates AJ, LaCroix AZ (1998b) Effect of alendronate on risk of fracture in women with low bone density but without vertebral fractures: results from the fracture intervention trial. JAMA 280(24): 2077-2082

Delmas PD, Balena R, Confravreux E, Hardouin C, Hardy P, Bremond A (1997) Bisphosphonate risedronate prevents bone loss in women with artificial menopause due to chemotherapy of breast cancer: a doubleblind, placebo-controlled study. J Clin Oncol 15(3): 955-962

Dowsett M, Jones A, Johnston SR, Jacobs S, Trunet P, Smith IE (1995) In vivo measurement of aromatase inhibition by Letrozole in postmenopausal patients with breast cancer. Clin Cancer Res 1: 1511-1515

Eastell R (1998) Drug therapy: treatment of postmenopausal osteoporosis. N Engl J Med 338(11): 736-746

Eastell R, Hannon RA, Cuzick J, Clack G, Adams JE (2002) Effect of anastrozole on bone density and bone turnover: results of the 'Arimidex' (anastrozole), Tamoxifen Alone or in Combination (ATAC) trial bone sub-protocol. 24th Annual Meeting American Society for Bone and Mineral Research, San Antonio, TX, USA. Abstract 1170

Ellis MJ, Coop A, Singh B, Mauriac L, Llombert-Cussac A, Janicke F, Miller WR, Evans DB, Dugan M, Brady C, Quebe-Fehling E, Borgs M (2001) Letrozole is more effective neoadjuvant endocrine therapy than tamoxifen for ErbB-1- and/or ErbB-2-positive, estrogen receptor-positive primary breast cancer: evidence from a phase III randomized trial. J Clin Oncol 19(18): $3808-3816$

Geisler J, King N, Anker G, Ornati G, Di Salle E, Lonning PE, Dowsett M (1998) In vivo inhibition of aromatisation by exemestane, a novel irreversible aromatase inhibitor, in postmenopausal breast cancer patients. Clin Cancer Res 4: 2089-2093

Geisler J, King N, Dowsett M, Ottestad L, Lundgren S, Walton P, Kormeset PO, Lonning PE (1996) Influence of anastrozole (Arimidex), a selective, non-steroidal aromatase inhibitor, on in vivo aromatisation and plasma oestrogen levels in postmenopausal women with breast cancer. $\mathrm{Br} J$ Cancer 74: 1286-1291

Gnant M, Hausmaninger H, Samonigg H (2002) Changes in bone mineral density caused by anastrozole or tamoxifen in combination with goserelin $(+/-$ zoledronate as adjuvant treatment for hormone receptor-positive premenopausal breast cancer: results of a randomized multicenter trial. Breast Cancer Res Treat 76(Suppl 1): S31 (abstract 12)

Goss P, Thompsen T, Banke-Bochita J (2002) A randomized, placebocontrolled, explorative study to investigate the effect of low estrogen plasma levels on markers of bone turnover in healthy postmenopausal 
women during the 12-week treatment with exemestane or letrozole. Breast Cancer Res Treat 76(Suppl 1): S76 (Abstract 267)

Goss PE, Ingle JN, Martino S, Robert NJ, Muss HB, Piccart MJ, Castiglione M, Tu D, Shepherd LE, Pritchard KI, Livingston RB, Davidson NE, Norton L, Perez EA, Abrams JS, Therasse P, Palmer MJ, Pater JL (2003) A randomized trial of letrozole in postmenopausal women after five years of tamoxifen therapy for early-stage breast cancer. N Engl J Med 349(19): $1793-1802$

Greep NC, Giuliano AE, Hansen NM, Taketani T, Wang HJ, Singer FR (2003) The effects of adjuvant chemotherapy on bone density in postmenopausal women with early breast cancer. Am J Med 114: $653-659$

Harper-Wynne C, Ross G, Sacks N, Dowsett M, Gui G (2001) Effects of the aromatase inhibitor letrozole in healthy postmenopausal women: rationale for prevention. American Society Clinical Oncology, May 12-15, 2001, San Francisco, CA, USA. Abstract 3091

Harris ST, Watts NB, Genant HK, McKeever CD, Hangartner T, Keller M, Chesnut III CH, Brown J, Eriksen EF, Hoseyni MS, Axelrod DW, Miller PD (1999) Effects of risedronate treatment on vertebral and nonvertebral fractures in women with postmenopausal osteoporosis. JAMA 282(14): $1344-1352$

Hashimoto K, Nozaki M, Inoue Y, Sano M, Nakano H (1995) The chronological change of vertebral bone loss following oophorectomy using dual energy $\mathrm{x}$-ray absorptiometry: the correlation with specific markers of bone metabolism. Maturitas 22(3): 185-192

Hasserius R, Karlsson M, Nilsson B, Redlund-Johnell I, Johnell O (2003) European Vertebral Osteoporosis Study. Prevalent vertebral deformities predict increased mortality and increased fracture rate in both men and women: a 10-year population based study of 598 individuals from the Swedish cohort in the European Vertebral Osteoporosis Study. Osteoporosis Int 14(1): $61-68$

Hillner BE, Ingle JN, Chlebowski RT, Gralow J, Yee GC, Janjan NA, Cauley JA, Blumenstein BA, Albain KS, Lipton A, Brown S, American Society of Clinical Oncology (2003) American Society of Clinical Oncology 2003 update on the role of bisphosphonates and bone health issues in women with breast cancer. J Clin Oncol 21: $4042-4057$

Howell A (2003) An assessment of fracture rates over time (between 6 and 48 months) in the ATAC (Arimidex, Tamoxifen, Alone or in Combination) trial. Eur J Cancer Suppl 1(5): S202

Ingle JN, Krook JE, Green SJ, Kubista TP, Everson LK, Ahmann DL, Chang MN, Bisel HF, Windschitl HE, Twito DI (1986) Randomized trial of bilateral oophorectomy versus tamoxifen in premenopausal women with metastatic breast cancer. J Clin Oncol 4(2): 178-185

Kanis JA, McCloskey EV, Powles T, Paterson AH, Ashley S, Spector T (1999) A high incidence of vertebral fracture in women with breast cancer. Br J Cancer 79(7-8): 1179-1181

Kaufmann M, Bajetta E, Dirix LY, Fein LE, Jones SE, Zilembo N, Dugardyn JL, Nasurdi C, Mennel RG, Cervek J, Fowst C, Polli A, di Salle E, Arkhipov A, Piscitelli G, Miller LL, Massimini G, The Exemestane Study Group (2000) Exemestane is superior to megestrol acetate following tamoxifen failure in postmenopausal women with advanced breast cancer: results of a phase III randomised double-blind trial. J Clin Oncol 18: $1399-1411$

Kristensen B, Ejlertsen B, Dalgaard P, Larsen L, Holmegaard SN, Transbol I, Mouridsen HT (1994) Tamoxifen and bone metabolism in postmenopausal low risk breast cancer patients: a randomized study. J Clin Oncol 12(5): $992-997$

Leather AT, Studd JW, Watson NR, Holland EF (1993) The prevention of bone loss in young women treated with GNRH analogues with 'add back' estrogen therapy. Obstet Gynecol 81(1): 104-107

Liberman UA, Weiss SR, Broll J, Minne HW, Quan H, Bell NH, RodriguezPortales J, Downs Jr RW, Dequeker J, Favus M (1995) Effect of oral alendronate on bone mineral density and the incidence of fractures in postmenopausal osteoporosis. N Engl J Med 333(22): 1437-1443

Locker G, Eastell R (2003) The time course of bone fractures observed in the ATAC ('Arimidex', Tamoxifen, Alone or in Combination) Trial. Proc Am Soc Clin Oncol 22: 25 (Abstract 98)

Lonning PE, Geisler J, Krag LE, Ottestad L, Bremnes Y, Hagen AI, Schlichting E, Polli A, Paolini J, Massimini G (2004) Effect of exemestane on bone: a randomized placebo controlled study in postmenopausal women with early breast cancer at low risk. J Clin Oncol 22(14S) (Abstract 518)

Love RR, Mazess RB, Barden HS, Epstein S, Newcomb PA, Jordan VC, Carbone PP, DeMets DL (1992) Effects of tamoxifen on bone mineral density in postmenopausal women with breast cancer. $N$ Engl J Med 326: $852-856$

Marks R, Allegrante JP, Ronald MacKenzie C, Lane JM (2003) Hip fractures among the elderly: causes, consequences and control. Ageing Res Rev 2(1): $57-93$

Martinetti A, Zilembo N, Ferrari L, Massimini G, Polli A, La Torre I, Giovanazzi R, Pozzi P, Bidoli P, De Candis D, Seregni E, Bombardieri E, Bajetta E (2003) Bone turnover markers and insulin-like growth factor components in metastatic breast cancer: results from a randomised trial of exemestane vs megestrol acetate. Anticancer Res 23: 3485-3491

Mouridsen $\mathrm{H}$, Gershanovich $\mathrm{M}$, Sun $\mathrm{Y}$, Perez-Carrion R, Boni C, Monnier A, Apffelstaedt J, Smith R, Sleeboom HP, Janicke F, Pluzanska A, Dank M, Becquart D, Bapsy PP, Salminen E, Snyder R, Lassus M, Verbeek JA, Staffler B, Chaudri-Ross HA, Dugan M (2001) Superior efficacy of letrozole versus tamoxifen as first line therapy for postmenopausal women with breast cancer: results of a phase 3 study of the international letrozole breast cancer group. J Clin Oncol 19(10): 2596-2606

Nabholtz JM, Buzdar A, Pollak M, Harwin W, Burton G, Mangalik A, Steinberg M, Webster A, von Euler M (2000) Anastrozole is superior to tamoxifen as first-line therapy for advanced breast cancer in postmenopausal women: results of a North American Multicenter Randomized Trial. J Clin Oncol 18(22): $3758-3767$

Paridaens R, Therasse P, Dirix L-Y (2004) First results of a randomized phase III trial comparing exemestane versus tamoxifen as first-line hormone therapy (HT) for postmenopausal women with metastatic breast cancer (MBC) - EORTC 10951 in collaboration with the exemestane working group and NCIC. Eur J Cancer Suppl 2(3): 126 (Abstract 241)

Perez EA, Josse RG, Pritchard KI, Ingle JN, Martino S, Findlay BP, Shenkier TN, Tozer RG, Palmer MJ, Shepher LE, Tu D, Goss ME (2004) Effect of letrozole versus placebo on bone mineral density in women completing $\geqslant 5$ years (yrs) of adjuvant tamoxifen: ncic ctg ma.17b. 27th Annual San Antonio Breast Cancer Symposium, December 8-11, 2004, San Antonio, Texas. Abstract 404

Powles TJ, Hickish T, Kanis JA, Tidy A, Ashley S (1996) Effect of tamoxifen on bone mineral density measured by dual energy X-ray absorptiometry in healthy premenopausal and post menopausal women. J Clin Oncol 14(1): $78-84$

Powles TJ, McCloskey E, Paterson AH, Ashley S, Tidy VA, Nevantaus A, Rosenqvist K, Kanis J (1998) Oral clodronate and reduction in loss of bone mineral density in women with operable primary breast cancer. J Natl Cancer Inst 90(9): 704-708

Reginster J, Minne HW, Sorensen OH, Hooper M, Roux C, Brandi ML, Lund B, Ethgen D, Pack S, Roumagnac I, Eastell R (2000) Randomized trial of the effects of risedronate on vertebral fractures in women with established postmenopausal osteoporosis. Vertebral Efficacy with Risedronate Therapy (VERT) Study Group. Osteoporosis Int 11(1): $83-91$

Reid IR, Brown JP, Burckhardt P, Horowitz Z, Richardson P, Trechsel U, Widmer A, Devogelaer JP, Kaufman JM, Jaeger P, Body JJ, Brandi ML, Broell J, Di Micco R, Genazzani AR, Felsenberg D, Happ J, Hooper MJ, Ittner J, Leb G, Mallmin H, Murray T, Ortolani S, Rubinacci A, Saaf M, Samsioe G, Verbruggen L, Meunier PJ (2002) Intravenous zoledronic acid in postmenopausal women with low bone mineral density. $N$ Engl J Med 346(9): 653-661

Riggs BL, Khosla S, Melton III LJ (1998) A unitary model for involutional osteoporosis: estrogen deficiency causes both type I and type II osteoporosis in post-menopausal women and contributes to bone loss in aging men. J Bone Miner Res 13(5): 763-773

Shapiro C, Manola J, Leboff M (2001) Ovarian failure after adjuvant chemotherapy is associated with rapid bone loss in women with early-stage breast cancer. J Clin Oncol 19(14): 3306-3311

Sluijmer AV, Heineman MJ, De Jong FH, Evers JL (1995) Endocrine activity on the postmenopausal ovary: the effects of pituitary down-regulation and oophorectomy. J Clin Endocrinol Metab 80: 2163-2167

Taylor CW, Green S, Dalton WS, Martino S, Rector D, Ingle JN, Robert NJ, Budd GT, Paradelo JC, Natale RB, Bearden JD, Mailliard JA, Osborne CK (1998) Multicenter randomized clinical trial of goserelin versus surgical ovariectomy in premenopausal patients with receptor-positive metastatic breast cancer: an intergroup study. J Clin Oncol 16(3): 994-999

van der Klift M, de Laet CE, Coebergh JW, Hofman A, Pols HA, Rotterdam Study (2003) Bone mineral density and the risk of breast cancer: The Rotterdam Study. Bone 32: 211-216 
Bone loss and aromatase inhibitors

$J$ Lester and R Coleman

Vehmanen L, Saarto T, Elomaa I, Makela P, Valimaki M, Blomqvist C (2001) Long-term impact of chemotherapy-induced ovarian failure on bone mineral density (BMD) in premenopausal breast cancer patients. The effect of clodronate treatment. Eur J Cancer 37: 2373-2378

Wheeler DL, Vander Griend RA, Wronski TJ, Miller GJ, Keith EE, Graves JE (1995) The short and long-term effects of methotrexate on the rat skeleton. Bone 16(2): 215-221
Writing Group for the Women's Health Initiative Investigators (2002) Risks and benefits of estrogen plus progestin in healthy postmenopausal women: principal results from the women's health initiative randomized controlled trial. JAMA 288(3): $321-333$

Zhang Y, Kiel DP, Kreger BE, Cupples LA, Ellison RC, Dorgan JF, Schatzkin A, Levy D, Felson DT (1997) Bone mass and the risk of breast cancer among postmenopausal women. $N$ Engl J Med 336: 611-617 